DEPARTMENT OF THE INTERIOR

U.S. GEOLOGICAL SURVEY

Electromagnetic, Magnetic, and Gravimetric Surveys at the $B i^{\prime} r$ Jarbuah Gold Prospect, Kingdom of Saudi Arabia

By C.H. Miller, A.A. Showail, M.A. Bazzari. I.A. Khoja, and M.0. Hajnur Open-File Report 90-327

Report prepared by the U.S. Geological Survey in cooperation with the Deputy Ministry for Mineral Resources, Saudi Arabia

This report is preliminary and has not been reviewed for conformity with U.S. Geological Survey editorial standards and stratigraphic nomenclature.

1/ USGS Mission Saudi Arabia 


\title{
ELECTROMAGNETIC, MAGNETIC, AND GRAVIMETRIC SURVEYS AT THE BI'R JARBUAH GOLD PROSPECT, KINGDOM OF SAUDI ARABIA
}

\author{
By \\ C. H. Miller, A. A. Showail, M. A. Bazzari, \\ I. A. Khoja, and M. O. Hajnur
}

\begin{abstract}
Bi'r Jarbuah is a potential gold-bearing site located east of the Ishmas gold district in the southeastern part of the Arabian Shield. Surface rocks are mostly diorite and granodiorite plutons and the metavolcanic and metasedimentary rocks they have intruded. Extensive thin alluvial deposits cover approximately 40 percent of the area studied. Diorite, granodiorite, aplite porphyry, granite, granite pegmatite, and mafic dikes intrude the plutons and the metavolcanic and metasedimentary rocks. Veins of quartz, carbonate materials, and associated carbonate-altered rocks containing limonite and hematite cut all rock types. The veins were extensively mined by ancient people, and recent trenching has revealed small amounts of free gold associated with these veins and adjacent altered country rocks.

A detailed search for gold and associated minerals was begun in the Bi'r Jarbuah area in 1988. Crone electromagnetic (CEM), magnetic, and gravimetric surveys were run in the areas of greatest interest. Anomalous areas are most interesting in the southern part of the area where linear magnetic and gravity anomalies trend east-northeast and overlap in large part. They are most prominent at or near the south end of a diorite pluton where some quartz veins mined by the ancients also trend northeast. A second area, at the extreme southern end of the survey, contains a large CEM anomaly that coincides with northeasttrending magnetic and gravity anomalies. Although this second area is largely overlain by alluvium, a major quartz vein strikes to the northeast in the adjacent bedrock.
\end{abstract}

\section{INTRODUCTION}

Bi'r Jarbuah (MODS 1454) is a gold-bearing area of potential economic value. It is in the southeastern part of the Arabian Shield (Figure 1), east of the Ishmas gold district and in the northern part of the Jabal Ishmas-Wadi Tathlith gold belt (Worl, 1979). The rocks at Bi'r Jarbuah are Proterozoic in age, and are partly covered by
Quaternary sedimentary deposits. Most of the exposed rocks are metamorphosed sedimentary and volcanic rocks that have been intruded by diorite and granodiorite plutons. The Proterozoic intrusive, metasedimentary, and metavolcanic rocks are all cut by numerous granodiorite, aplite porphyry, granite, granite pegmatite, and mafic dikes. Quartz and carbonate veins cut all rock types.

Extensive ancient exploration and mining is indicated by the presence of many trenches, dumps, 
and particularly the scattered milling stones that imply the presence of gold. More recent geologic investigations of the Bi'r Jarbuah ancient mine sites have determined that Bi'r Jarbuah may still contain ore of economic value (Worl, 1979). Consequently, geologic mapping, geochemical and geophysical surveying, trenching (during which a small amount of free gold was found), and drilling were begun in 1988. This report describes the geophysical surveys and the geologic interpretation of the geophysical data from these investigations.

In order to conduct systematic geophysical studies at Bi'r Jarbuah, a station grid was surveyed that encompassed most of the ancient mine sites and contiguous areas. The grid was $2 \mathrm{~km}$ long by $1 / 2 \mathrm{~km}$ wide, and was marked by stakes placed on $50-\mathrm{m}$ centers. The grid origin $(0,0)$ is at lat $20^{\circ} 52.17 \mathrm{~N}$., long 4335.01' $\mathrm{E}$. All directions in this report are referenced to true north. Grid north is $N .25^{\circ} \mathrm{E}$., but station coordinates are given in terms of simply N-S and E-W on this grid. Electromagnetic, magnetic, and gravimetric surveys were then carried out over the gridded area. Both the gravity and the magnetic surveys occupied all the 50-m surveyed grid points. The gravity survey occupied additional stations at 25-m intervals along the $\mathrm{N}-\mathrm{S}$ baseline. The electromagnetic (EM) surveys occupied all the grid points to the east; some EM grid points over the diorite pluton to the west were not used because the data in this part of the grid are relatively featureless. Additional EM stations were added to the southeastern part of the grid to help define significant anomalies. The various reduced geophysical data are presented on individual contour maps of equal scale. A summary geophysical map with generalized geology is also included for the mutual comparison of the geophysical anomalies and their correlation with geology.

The geophysical surveys were conducted in accordance with the Ninth Extension to the Work Agreement between the Directorate General of Mineral Resources (DGMR), Jeddah, Saudi Arabia, and the United States Geological Survey (USGS) Saudi Arabian Mission under Subprojects 6.22.03 and 3.11.29.

\section{ACKNOWLEDGMENTS}

We thank C.L. Long and B.M. Walker for their thorough technical reviews and suggestions. Walker further provided much fieldcamp support as well as geologic information. Said Liban was party chief of land surveying. Larry V. Balboda did most of the manuscript word processing.

\section{GEOLOGY}

The geology of the Bi'r Jarbuah site was mapped by Worl (1979), Bishop (1982), and Walker and others (1989) and is generalized on the plate (Map D). This map covers an area about $500 \mathrm{~m}$ wide (grid coordinates $250 \mathrm{~W}$. to $250 \mathrm{E}$.) and $1,800 \mathrm{~m}$ long $(1000 \mathrm{~S}$. to $800 \mathrm{~N}$.). The geology at the site is characterized by metasedimentary and metavolcanic rocks that have been intruded by plutons and dikes. About $\mathbf{4 0}$ percent of the survey area is covered by Quaternary deposits.

More than 50 percent of the bedrock outcrops are metavolcanic and metasedimentary rocks of Proterozoic age. These rocks, along with intermixed augen gneiss, occur in a long discontinuous swath in the eastern half of the Bi'r Jarbuah mining site. The rest of the bedrock outcrops, covering nearly half the area, are diorite that intruded the metavolcanic and metasedimentary rocks during Proterozoic time. Most of the diorite is included in a pluton that crops out along the west side of the grid. However, small outliers of diorite occur a short distance east of the north end of the pluton. The emplacement of the diorite pluton apparently upturned the surrounding metasedimentary and metavolcanic layered rocks, as they presently dip eastward away from the pluton at moderate angles (about $50^{\circ}$ ) and strike subparallel to the contact (Walker and others, 1989).

Granodiorite stocks and dikes, which were emplaced following the intrusion of the diorite pluton, cut the metavolcanic and metasedimentary rocks, as well as the diorite. Still younger dikes of aplite, granite, granitic pegmatite, and mafic rocks occur throughout the area and, in turn, cut the granodioritic rocks.

A northward structural trend is indicated by the drainage pattern, by many of the dikes and veins in the eastern part of the grid, and by the granodiorite stocks that intrude the large diorite pluton. Some dikes appear to wrap around the northern end of the pluton along bedding planes in the layered rocks, nearly subparallel to the pluton contact. Pegmatite dikes trend eastward and cross the pluton boundary between 150S. and 250S. and at about 350N. (Map D). Mafic dikes cross the pluton boundary from about $200 \mathrm{~N}$. to $700 \mathrm{~N}$., but they are few in number. 
Two sets of faults are evident in the area, and both sets are located in the northern half of the grid: one set trends northeast, the other trends northwest. The northwest-trending set may coincide with the Najd faults described by Johnson and others (1987).

Vein material includes quartz and carbonate minerals and associated carbonate-altered rocks containing iron, limonite, and hematite. The quartz veins were mined extensively by the ancients, and rubble and waste dumps are very much in evidence. Visible free gold has been found in quartz veins at the ancient sites, and ancient mining activity was apparently focused on these veins.

Sulfides are also in evidence throughout the site and they have been encountered in drill holes. Of particular importance is the presence of arsenopyrite, which is frequently associated with gold. Pyrrhotite, which is magnetic, is the principal sulfide mineral and is also associated with the arsenopyrite.

While the wadis were found to contain some moisture during the surveys, the exposed bedrock was dry. Drilling did not encounter any static water levels (Walker and others, 1989); in fact, drilling fluid was lost to the media. The water table appears to be at considerable depth and, therefore, may not be a factor in the interpretation of geophysical data.

\section{GEOPHYSICAL TECHNIQUES AND ROCK PROPERTIES}

Electromagnetic, magnetic, and gravimetric techniques were used in prospecting for mineralized areas at Bi'r Jarbuah. Each of the techniques responds to different earth parameters.

\section{Electromagnetics}

The Crone (Crone, 1966) "shootback" electromagnetic method (CEM) was applied at the B'ir Jarbuah site. In this method, a primary coil of wire is energized such that a time-varying magnetic field is induced into the Earth. This primary field creates electrical currents in the Earth that have an associated secondary magnetic field. A second coil that is identical to the primary coil and is placed at a known distance from the first coil is used to detect the secondary magnetic field. Each coil is used first as a transmitting coil and then as a receiver; the results are subsequently averaged to obtain a representative dip angle between the primary and secondary magnetic fields. The two main advantages of this system are (1) the two coils do not have to be physically connected by wire, and (2) terrain effects are largely negated by the reversed readings.

The variation in the resultant dip angles is related to several factors that indicate the conductivity of the underlying rocks. Conductivity generally increases as water content, water salinity, and rock porosity increase. A volumetric increase in metallic minerals, clay, and graphite will also increase electrical conductivity. Conversely, conductivity is low for dry country rock that is barren of either mineralization, graphite, or clay. At Bi'r Jarbuah, finely divided graphite is probably more conductive than either clay or metallic minerals, and although the depth of penetration for these electromagnetic soundings was above static water level, perched water in partly saturated media may have locally increased relative conductivity.

Dip angle may also be influenced by other factors, such as homogeneity and conductivity of the medium and the depth to and width of the conductor. The combinations of causative factors are infinite and the interpretations in this area tend to be qualitative. For example, if a medium is homogeneous, the dip angle may be zero (Crone, 1966). Also, a profile run perpendicular across a relatively narrow buried vertical conductor might exhibit positive dip angles over the conductor, but would exhibit negative dip angles over the flanks of the conductive body if the depth to the conductive body were less than the width of the conductor. On the other hand, a near-surface conductive body wider than the coil spacing might exhibit negative dip angles.

\section{Magnetics}

A magnetic survey consists of measuring the Earth's total magnetic field with two precession magnetometers (Breiner, 1973). One magnetometer records continuously at a base, while another "roving unit" records at discrete field stations. Field data are corrected for diurnal changes by subtracting the base value from the station value at equivalent times. At Bi'r Jarbuah, the Earth's total "undisturbed" field was in excess of 40,000 nanoTeslas (nT), whereas the local perturbation (anomaly) was only a few hundred nanoTeslas. To facilitate data handling, an arbitrary "tare" of $39,950 \mathrm{nT}$ was subtracted from the total reading and the remainder plotted and contoured. 
Anomalies are caused by the presence of magnetic iron. Magnetic materials in the Bi'r Jarbuah area include at least magnetite and pyrrhotite. These minerals are usually disseminated throughout the media, but they may occur in relatively small local concentrations. If magnetic iron is present, an anomaly will usually be additive (positive) to the Earth's field when measured directly over the causative body.

\section{Gravity}

Gravity measurements at the site were referenced to a temporary base of the International Gravity Standardization Net of 1971 (Morelli and others, 1971) set in the study area. Standard instrument corrections were applied and the Bouguer correction was made using a density of $2.67 \mathrm{~g} / \mathrm{cm}^{3}$ the "standard" density used in reductions because it is the approximate average for the Earth's crust. Terrain corrections were not calculated, as they were deemed unnecessary because of the flat terrain at the study area. The difference between corrected data (without terrain corrections) and theoretical gravity for a given latitude is called the simple Bouguer anomaly and on most continents, including most of the Arabian Peninsula, it is negative. The greater the absolute value of the simple Bouguer anomaly, the smaller is the gravitational attraction.

Bouguer anomalies vary not only inversely to the square of the distance to a causative body, but also directly to the density of the body. Some parameters that affect the density of rocks (Miller, Showail and others, 1989) include inherent mineral composition and processes that increase density, such as diagenesis and metamorphism. The volcanic and sedimentary rocks in the Bi'r Jarbuah area, for example, may originally have had a significant amount of incipient porosity, then been subject to increasing compaction and temperature, and, with the passage of time, been metamorphosed and made yet more dense. On the other hand, plutonic rocks are inherently nonporous; and some, such as the quartzo-feldspathic plutonic rocks in the study area, should be less dense than iron- and manganese-rich metavolcanic and metasedimentary rocks. Quaternary deposits are mostly unconsolidated and are of such low density that they produce gravity lows compared with bedrock.

\section{GEOLOGIC INTERPRETATION OF GEOPHYSICAL DATA}

Grid points, on contour maps of the electromagnetic (Map A), magnetic (Map B), and gravity (Map C) measurements, are equidistant, which eliminates bias in the contouring of all the data.

\section{Electromagnetics}

The electromagnetics map of (Map A) shows CEM (Crone electromagnetic) anomalies that range from about $+10^{\circ}$ to $-70^{\circ}$ tilt angle. While conductive anomalies may cause either positive or negative tilt angles, depending on the depth and configuration of the causative body, experience on the Arabian Shield has shown that negative anomalies are most often associated with conductive bodies (Miller, Bazzari, and others, 1989). The north-trending neutralto-positive tilt angles are clearly coincident with the intrusive contact between the diorite pluton to the west and the metavolcanic and metasedimentary rocks to the east (Map D), except to the north, where two zero contours occur in an area where the geology has not been mapped.

Negative CEM anomalies also correlate strongly with alluvium both as a north-south trend along the east side the map and around the south end of the diorite pluton. The negative anomalies with higher amplitude appear to correlate with the thicker alluvial deposits. The CEM anomalies associated with alluvium may be caused by the greater amounts of moisture and clay in the wadi sediments rather than by the underlying bedrock. Also, they may mask other conductive anomalies caused by the presence of mineralization, graphite, or clay-rich fault gouge in bedrock buried by the alluvium.

Notable exceptions to the correlation of negative tilt-angle anomalies with alluvium are the $-40^{\circ}$ anomaly centered at $150 \mathrm{E}$. and $50 \mathrm{~S}$., and the $-20^{\circ}$ low at about $100 \mathrm{E}$. and $250 \mathrm{~N},-450 \mathrm{~N}$. The $-40^{\circ}$ anomaly, for example, straddles aplite dikes that trend northward under the alluvium, and the $-20^{\circ}$ low is on the trend of veined rocks intersected by drill hole 6. Possible causes of the negative anomalies include a stringer of argillite, as observed in drill hole 6 , or graphite, which has been observed several 
hundred meters north of the minus- $20^{\circ}$ tilt-angle anomaly. However, the most likely cause of these CEM anomalies is the presence of sulfides associated with dikes and veins (Walker, personal commun., 1989). The sulfides may be conductive in both altered and unaltered states, but are oxidized down to several tens of meters in drill hole 6 .

\section{Magnetics}

The magnetic contour map for the Bi'r Jarbuah site (Map B) uses a 25-nT contour interval. The magnetic field ranges from about $100 \mathrm{nT}$ to $250 \mathrm{nT}$.

Walker and others (1989) identified as much as 10 percent magnetic pyrrhotite in the metasedimentary and metavolcanic rock from core drilling in the northern part of the grid. Pyrrhotite is at least twice as abundant as pyrite. The prominent magnetic anomalies in the south may be caused by a greater abundance of pyrrhotite than in the north.

From about 300S. southward, the principal magnetic trends strike approximately east-northeast, which is nearly perpendicular to the strike of many of the dikes in the area (Map D). The most prominent east-northeast-trending magnetic high is that marked by the 200-250-nT contours. This high crosses the south end of the diorite pluton, the metavolcanic and metasedimentary rocks, and the alluvium abutting the pluton on the east. The 250-nT anomaly (in this trend) farthest to the east-northeast is centered over granite-pegmatite dikes and thick quartz veins in metavolcanic and metasedimentary country rocks. South of this high are two parallel anomalies, one low and one high. The magnetic low includes three 100-nT centers located chiefly over metasedimentary and metavolcanic rocks, although the northeast end of the anomaly is located over alluvium and the western anomaly is located near dikes and veins. The 175-nT high south of the three 100-nT lows trends along the strike of some quartz veins and associated carbonate-altered rocks containing oxidized iron; some of the quartz veins near this anomaly were mined by the ancients.

Trends in the magnetic contours north of about 300S. are not as apparent as those to the south. The anomalies to the north also cross geologic contacts, seemingly at random, although some do trend eastnortheast like those to the south. Alternate low and high patterns again occur along 50N. (75-nT low), $250 \mathrm{~N}$. (200-nT high), and 350N. (150-nT low). The $200-\mathrm{nT}$ high located along $250 \mathrm{~N}$. is centered over granite pegmatite dikes intruded into metased- imentary and metavolcanic rocks. Small outcrops of diorite occur in the same area. The steepest magnetic gradient in the area is between the 250-nT high at $400 \mathrm{~N}$., $100 \mathrm{~W}$., and the $75-\mathrm{nT}$ low at $450 \mathrm{~N}$., $100 \mathrm{~W}$. Both anomalies, identified by measurements at only one station each, are near dikes, including some of the very few mafic dikes in the grid, and with ancient mines located at the edge of the diorite pluton. These anomalies also indicate the presence of sulphide mineralization at depth.

\section{Gravity}

The gravity measurements are contoured on Map C in tenths of a milligal (mgal); all values are negative. The larger the absolute Bouguer gravity value for a given depth, the smaller the gravitational attraction. That is, a minus-70-mgal reading indicates the presence of rocks that are less dense than those with a $-65.5 \mathrm{mgal}$ reading.

The gravity field shown on Map $\mathrm{C}$ ranges from about $-70.1 \mathrm{mgal}$ (450S., 250W.) to about $-69.1 \mathrm{mgal}$ (700-950N., 250E.). The field shows linear northeastward trends, as do the gravity contours on Map C and some of the dikes and veins on Map D. The gravity field is lowest (has the highest absolute values) over the diorite to the west, and greatest over the metasedimentary and metavolcanic rocks to the east, and it has a gradient of approximately 0.6 to 0.7 mgal in $500 \mathrm{~m}$. While the gravity field is apparently influenced by the diorite located along the west side of the grid, the lowest part of the field over the diorite does not correlate with the slight topographic highs, as might be the case if terrain corrections were not made. Instead, the low over the diorite on Map C seems to follow the trend of the granodiorite stocks centered at $100 \mathrm{~S}$., $100 \mathrm{~N}$., and $450 \mathrm{~N}$. (Map D). These lows may suggest a contiguous granodiorite intrusion, and the stocks may represent the apical portion of the intrusion (B. Walker, written commun., 1989).

A conspicuous gravity high described by the minus-69.6-mgal contour is centered in the minus-69.5-mgal contour at about 50W. and $600 \mathrm{~S}$. This high trends east-northeastward over the southeastern end of the diorite pluton. The gravity high also corresponds closely with the equivalent magnetic high shown on Map B. These anomalies indicate that rocks of relatively greater density and magnetism are present at depth. However, the CEM contour map (Map A) does not suggest that the rocks causing the gravity and magnetic anomalies are conductive within a few tens of meters of the surface. 
In addition to the east-northeast trend of the gravity anomalies over the southern end of the diorite, some carbonate-altered zones and quartz veins also strike in this same direction. Four of these vein systems are shown on Map $D$, and all are located south of the grid baseline. The first of these vein systems extends from about $100 \mathrm{E}$., 950S. to $200 \mathrm{E}$., $800 \mathrm{~S}$., the second from $50 \mathrm{~W}$., $850 \mathrm{~S}$. to 0,750 S., the third from 175W., 450S. to $100 \mathrm{~W}$., 350S., and the fourth from $250 \mathrm{~W}$., 200S. to 50W., 50S. Extensive ancient workings are also located along these veins. There is only a general correlation between the gravity-low anomalies and the alluvium. This observation implies that the alluvial deposits are relatively thin except, perhaps, at the extreme south end of the grid and where minus-69.8- and minus$69.7-\mathrm{mgal}$ lows occur over wadi deposits. The minus-69.8-mgal low also corresponds to a conductive zone (Map A) over the alluvium.

Numerous other small gravity anomalies occur at scattered locations across the Bi'r Jarbuah site. A small, but conspicuous high of $-69.7 \mathrm{mgal}$ is situated at $50 \mathrm{~W}$. and $300 \mathrm{~N}$. This gravity value may have been simply a bad reading, even though it was repeated. Although the station was located on a granodiorite dike, there is no gravity trend paralleling the dike. The dike, though having a long exposure, is only a few meters wide. Perhaps only trends wider than a few tens of meters are fully represented by the contour data.

\section{SUMMARY AND CONCLUSIONS}

Map E summarizes some of the more prominent geophysical anomalies of the Bi'r Jarbuah site: CEM (Map A), magnetic (Map B), and gravimetric (Map C).

The most prominent anomalies shown on Map $E$ are the repetitive highs and lows south of about the 300S. grid line. These anomalies are defined by magnetic, gravimetric, and electromagnetic data. The magnetic and gravity anomalies trend east-northeast, which is essentially perpendicular to other geologic trends in the area, except for those of some carbonate-altered zones and quartz veins. The gravity and magnetic anomalies with the highest amplitude trend across the southern part of the diorite pluton, where carbonate-altered and quartz-vein-bearing rocks also occur. The superimposed gravity and magnetic-high anomalies indicate the presence of a relatively dense magnetic body at depth; the corresponding rock type may have a more basic composition than that of the surrounding sedimentary-volcanic protolith. The anomalous trends over the diorite and at a distance from it may relate to the similarly oriented vein systems.

The presence of magnetic anomalies of limited areal extent are indicated by a high along $250 \mathrm{~N}$. and by two lows along $50 \mathrm{~N}$. Also of particular interest are the high and low magnetic anomalies located between $400 \mathrm{~N}$. and $450 \mathrm{~N}$., which correlate with mafic dikes in an area of many veins and ancient workings.

The CEM technique is usually a very reliable indicator of the presence of buried conductive zones and, hence, mineralized zones (Miller, Bazzari, and others, 1989). However, most of the CEM anomalies at Bi'r Jarbuah are probably caused by moist alluvium along the wadis; but mineralized zones may also have some surface expression. Two CEM anomalies located over exposed bedrock at 50S., $150 \mathrm{E}$. ( $-40^{\circ}$ tilt angle) and $350 \mathrm{~N}$., 100E. $\left(-20^{\circ}\right.$ tilt angle) (on Map E) are examples of this phenomenon in that they coincide with dikes and veins.

The geophysical surveys successfully delineated some anomalies at depth that may be caused by mineralization. We recommend further exploratory drilling, particularly in the vicinity of the east-northeast-trending anomalies south of $300 \mathrm{~S}$. Special attention is recommended for (1) the vein deposits that disappear under the alluvium at about 925S., 140E. and have associated magnetic and CEM anomalies, and (2) the overlapping magnetic and gravity anomalies near the vein deposits between 500 S. and 6005 . located at about $50 \mathrm{E}$.

\section{DATA STORAGE}

All field and laboratory data for this report, including field electromagnetic, magnetic, and gravimetric readings, field and topographic maps, photographs, terrane corrections, and printouts of reduced data are stored in Data File USGS-DF-10-3 in the Jeddah office of the U.S. Geological Survey Saudi Arabian Mission.

No updated information was added to the Mineral Occurrence Documentation System (MODS) data bank, and no new files were established. 


\section{REFERENCES CITED}

Bishop, D.T., 1982, Appraisal of gold potential in the Bi'r Juqjuq-North Tathlith region Kingdom of Saudi Arabia: Saudi Arabian Deputy Minister for Mineral Resources Open-File Report RF-OF-02-4, 26 p.

Briener, S., 1973, Applications manual for portable magnetometers: EG \& G, 395 Java Drive, Sunnyvale, California 94086, $58 \mathrm{p}$.

Crone, J. D., 1966, The development of a new ground electromagnetic method for use as a reconnaissance tool, in Mining geophysics case histories, v.1: Society of Exploration Geophysicists, pp. 151-156.

Johnson, P. R., Scheibner, Erwin, and Smith, E. A., 1987, Basement fragments, accreted tectonostratigraphic terranes, and overlap sequences-Elements in the tectonic evolution of the Arabian Shield: American Geophysical Union, Geodynamics Series, v. 19, pp. 323-343.

Miller, C.H., Bazzari, M.A., Showail, A.A., Hajnur, M.O., and Khoja, I.A., 1989, Geophysical prospecting at the Jabal Mardah gossans, Kingdom of Saudi Arabia: Saudi Arabian Directorate General of Mineral Resources Open-File Report USGS-OF-09-7, 21 p.
Miller, C. H., Showail, A. A., Kane, M. F., Khoja, I. A., and Al Ghamdi, S. A., 1989, A gravity survey of parts of quadrangles $26 \mathrm{E}, 26 \mathrm{~F}, 27 \mathrm{E}$, and 27F, northeastern Arabian Shield, Kingdom of Saudi Arabia: Saudi Arabian Directorate General of Mineral Resources Open-File Report USGS-OF-09-3, 19 p Eanadian Journàl
of Earth Sclence, in press

Morelli, C., Gantar, C., Honkasalo, T., McConnell, R. K., Tanner, J. G., Szabo, B., Uotila, U., and Whalen, C. T., 1971, The international gravity standardization net: International Association of Geodesy Special Publication No. 4, 194 p.

Walker, B. M., El-Komi, M., Taleb, M. B., and Christian, R.,1989, Geology and mineralization of the Bi'r Jarbuah gold prospect, Saudi Arabia: Saudi Arabian Directorate General of Mineral Resources Technical Record USGS-TR-10-2 (in prep.)

Worl, R.G., 1979, The Jabal Ishmas-Wadi Tathlith gold belt, Kingdom of Saudi Arabia: U.S. Geological Survey Saudi Arabian Mission Project Report 264, 108 p. USGS Open-File Report 79-1519

The work on which this report was based was performed in accordance with a cooperative agreement between the U.S. Geological Survey and the Ministry of Petroleum and Mineral Resources. This report is a product of the 1408 DMMR Work Program and is listed as Subprojects 6.22.03 and 3.11.29. The information contained in this report is a product of Ministry work; if the information herein is used in any form, either quoted or paraphrased, this report should be properly cited using the full serial number, the author's name(s), and the date (year) of publication.

The correct citation for this report is as follows:

Miller, C.H., Showail, A.A., Bazzari, M.A., Khoja, I.A., and Hajnur, M.O., 1989, Electromagnetic, magnetic, and gravimetric surveys at the Bi'r Jarbuah gold prospect, Kingdom of Saudi Arabia: Saudi Arabian Directorate General of Mineral Resources Open-File Report USGS-OF-10-5, plate with pamphlet, scale 1:5,000.

This report was technically reviewed by C.L. Long and B.M. Walker. The report has been edited and reviewed for conformity with U.S. Geological Survey Open-File standards. Product names used in this report are for descriptive purposes and in no way imply endorsement by the U.S. Geological Survey. 